\title{
Formation of Clogging Materials in an Immersed Nozzle during Continuous Casting of Titanium Stabilized Stainless Steel
}

\author{
Yang GAO and Kenichi SORIMACHI'
}

Kawasaki Steel Techno-Research Corporation, Kawasaki-cho, Chuo-ku, Chiba, Chiba-ken, 260 Japan.

1) Iron and Steel Research Laboratories, Kawasaki Steel Corporation, Kawasaki-cho, Chuo-ku, Chiba, Chiba-ken, 260 Japan.

(Received on September 1. 1992; accepted in final form on November 20, 1992)

\begin{abstract}
The formation of clogging materials in an immersed nozzle during the continuous casting of Ti-stabilized stainless steel was studied by plant and laboratory experiments. The major materials deposited were globular $\mathrm{Ti}$ oxide as curved chain and $\mathrm{Al}_{2} \mathrm{O}_{3}$ as large, black agglomerates. On the contrary, TiN and $\mathrm{Al}_{2} \mathrm{O}_{3}$ were observed in the steel in the tundish, and $\mathrm{Ti}$ oxide was scarcely found. The curved chain of globular $\mathrm{Ti}$ oxide could only have been formed by reoxidation after nitrogen absorption in the laboratory experiments. The formation mechanism for $\mathrm{Ti}$ oxide from $\mathrm{TiN}$ decomposition is proposed for the clogging behaviour of Ti-stabilized stainless steel.
\end{abstract}

KEY WORDS: continuous casting; clogging; non-metallic inclusion; immersed nozzle; Ti-stabilized stainless steel.

\section{Introduction}

Several studies ${ }^{1-3)}$ have been performed on clogging phenomena in an immersed nozzle during the continuous casting of aluminum-killed steel. In these studies, the deposited substances were identified as deoxidation and reoxidation products already present in the steel melt. $\mathrm{Al}_{2} \mathrm{O}_{3}$ inclusions have a tendency to adhere to the refractory surface due to the non-wetting phenomena between inclusions and the steel melt.

Hasegawa ${ }^{4)}$ has reported the same mechanism in the case of Ti-stabilized stainless steel. The major deposited materials were made up of $\mathrm{Al}_{2} \mathrm{O}_{3}$ and $\mathrm{TiN}$ inclusions in the ladle or tundish. These inclusions were deposited on the nozzle surface during passing through the immersed nozzle.

Takahashi et al. ${ }^{5)}$ have investigated nozzle clogging with high alloy steel containing $\mathrm{Ti}$ and $\mathrm{Al}$, with special attention to the $\mathrm{Al} / \mathrm{Ti}$ ratio. The deposited materials were made up of $\mathrm{Al}_{2} \mathrm{O}_{3}$ and $\mathrm{Ti}_{3} \mathrm{O}_{5}$, and the effect of TiN on nozzle clogging was comparatively small. From these studies it can be concluded that the deposited materials were already present in the steel melt in the tundish.

On the contrary, operational experience shows that stainless steel with $\mathrm{Ti}$ content exceeding $0.15 \%$ promotes the clogging significantly. However, its mechanism is not yet sufficiently clear. The present study was performed to make clear the effect of $\mathrm{Ti}$ and $\mathrm{N}$ on the formation of clogging material by laboratory experiments and metallurgical observations of plant samples.

\section{Experimental Methods}

\subsection{Plant Tests}

After the completion of casting, the nozzle was retrieved. The chemical composition and microstructure of the deposited particles were examined by optical microscope, EPMA, EDXA and X-ray diffraction methods.

To compare the chemical composition, size and morphology of the inclusions between the deposited particles and those in the steel in the tundish, samples from the tundish were investigated by the electron beam extraction method. The chemical composition of the steel investigated is shown in Table 1.

\subsection{Laboratory Tests}

The chemical composition of the steel used for the laboratory tests is also shown in Table 1 , Ti content

Table 1. Chemical compositions of the steel investigated. (mass\%)

\begin{tabular}{lcccccccccc}
\hline & $\mathrm{C}$ & $\mathrm{Si}$ & $\mathrm{Mn}$ & $\mathrm{P}$ & $\mathrm{S}$ & $\mathrm{Al}$ & $\mathrm{Cr}$ & $\mathrm{Ti}$ & $\mathrm{N}$ \\
\hline Plant test & 0.02 & 0.33 & 0.29 & 0.033 & 0.003 & 0.013 & 11.4 & 0.16 & 0.02 \\
Laboratory test & 0.02 & 0.45 & 0.30 & 0.030 & 0.001 & 0.020 & 11.2 & $0.2-1.0$ & 0.02 \\
\hline
\end{tabular}




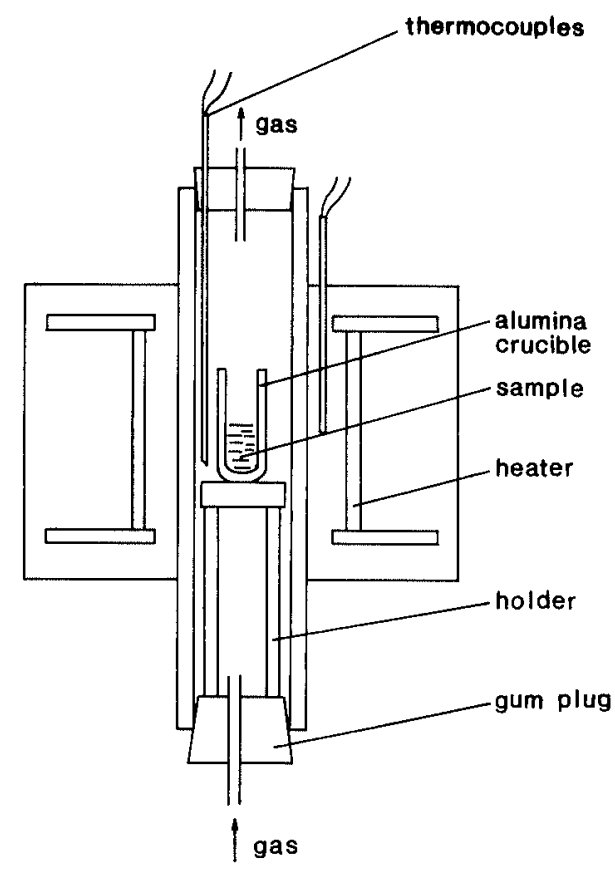

Fig. 1. Apparatus for the laboratory experiments.

being varied from $0.2 \%$ to $1.0 \%$. The steel ingot of $1.5 \mathrm{~kg}$ was melted in an alumina crucible of $60 \mathrm{~mm}$ internal diameter and $140 \mathrm{~mm}$ height at $1550^{\circ} \mathrm{C}$ for $30 \mathrm{~min}$ to separate the non-metallic inclusions. The oxygen content of the sample was less than $20 \mathrm{ppm}$, and $2 \mathrm{~mm}$ thickness was removed from the surface of the ingot. Small samples of $30 \mathrm{~g}$ were cut out for the subsequent experiments, the experimental apparatus being shown in Fig. 1.

The samples just described were melted at $1570^{\circ} \mathrm{C}$ under an $\mathrm{Ar}$ atmosphere in a high-alumina crucible $\left(\mathrm{Al}_{2} \mathrm{O}_{3}=99 \%\right)$ of $18 \mathrm{~mm}$ internal diameter.

The treatments shown in Fig. 2 were then applied in order to clarify the formation mechanism for the clogging materials in the immersed nozzle during the continuous casting operation.

Method No. 1: The remelted sample was cooled to $1525^{\circ} \mathrm{C}$. Then, the $\mathrm{Ar}$ gas was changed to an $\mathrm{Ar}-\mathrm{O}_{2}$ gas mixture $\left(P_{\mathrm{O}_{2}}=0.25 \mathrm{~atm}\right.$, gas flow rate $\left.=5 \mathrm{l} / \mathrm{min}\right)$. The sample was kept for $10-30 \mathrm{~min}$ at $1525^{\circ} \mathrm{C}$, and cooled to room temperature.

Method No. 2: The sample was remelted under an Ar atmosphere at $1570^{\circ} \mathrm{C}$. Then, the atmosphere was changed to gas mixture of $\mathrm{Ar}-\mathrm{N}_{2}\left(P_{\mathrm{N}_{2}}=0.25 \mathrm{~atm}\right.$, gas flow rate $=5 \mathrm{l} / \mathrm{min}$ ). After keeping for $30 \mathrm{~min}$, the sample was cooled to room temperature.

Method No. 3: After the same treatment as that in Method No. 2, the sample was cooled to $1525^{\circ} \mathrm{C}$. Then, the atmosphere was changed to an $\mathrm{Ar}-\mathrm{O}_{2}$ gas mixture $\left(P_{\mathrm{O}_{2}}=0.07 \mathrm{~atm}\right.$, gas flow rate $\left.=5 \mathrm{l} / \mathrm{min}\right)$. The sample was kept for $1-5 \mathrm{~min}$ at $1525^{\circ} \mathrm{C}$.

Method No. 4: After the same treatment as that in Method No. 2, the sample was cooled to $1525^{\circ} \mathrm{C}$, and $0.3 \mathrm{~g}$ of $\mathrm{FeO}$ powder was added to the surface of the sample. The furnace was kept for $10 \mathrm{~min}$ at $1525^{\circ} \mathrm{C}$, and cooled to room temperature.

Samples of each were cut out longitudinally for the

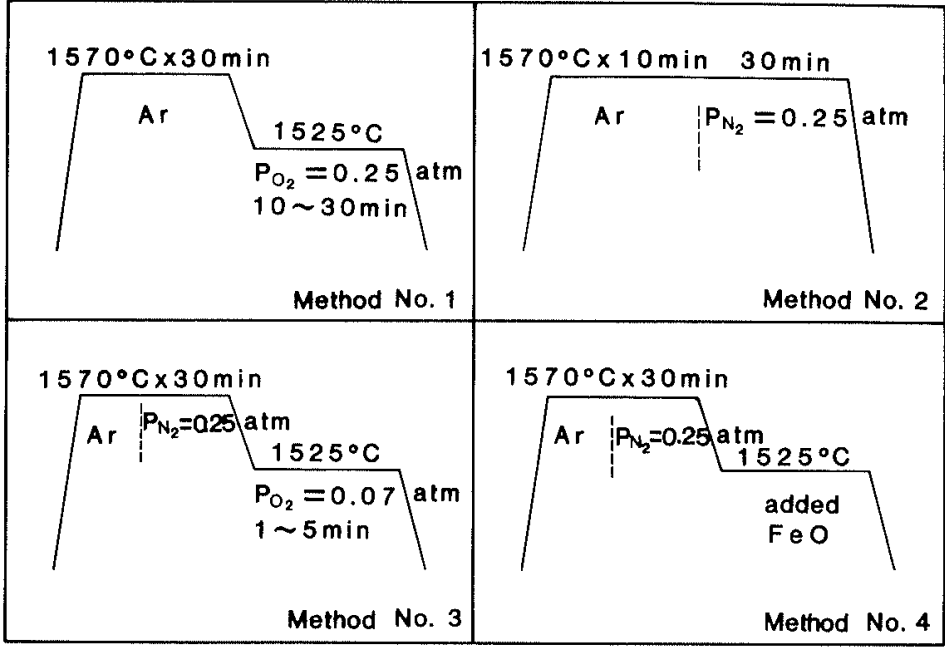

Fig. 2. Thermal treatment and atmosphere used in the laboratory experiments.

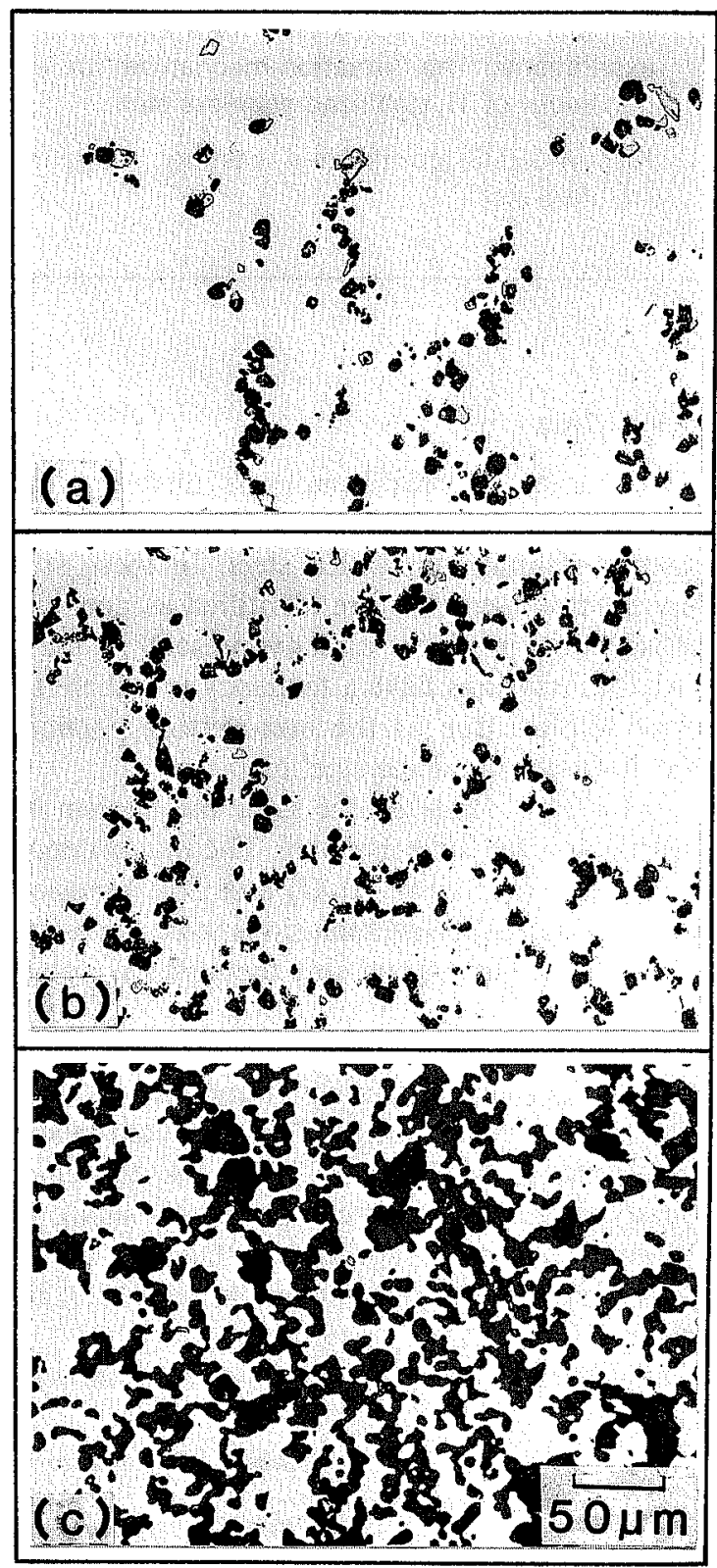

Fig. 3. Microstructure of the nozzle deposit.

(a), (b) and (c) show material at 14, 12 and $4 \mathrm{~mm}$ from the refractory surface, respectively. 
microstructural observation.

\section{Experimental Results}

\subsection{Analysis of the Deposited Substances}

The deposition of $\mathrm{Al}_{2} \mathrm{O}_{3}$ during the continuous casting of aluminum-killed steel is usually confined to the exit portion of the immersed nozzle. However, in the case of Ti-stabilized stainless steel, the clogging material was mainly observed at the top of the immersed nozzle contiguous with the tundish. The deposited substances of $15 \mathrm{~mm}$ thickness adhering to the inner surface of the nozzle was collected. The microstructure of the clogging materials is shown in Fig. 3. Figs. $3(\mathrm{a}), 3(\mathrm{~b})$ and 3 (c) represent the microstructure of the materials at 14,12 and $4 \mathrm{~mm}$ away from the refractory surface, respectively.

Transparent granular TiN and gray granular $\mathrm{Ti}$ oxides can be seen in Fig. 3(a). In Fig. 3(b), the proportion of gray granular $\mathrm{Ti}$ oxide is more compared

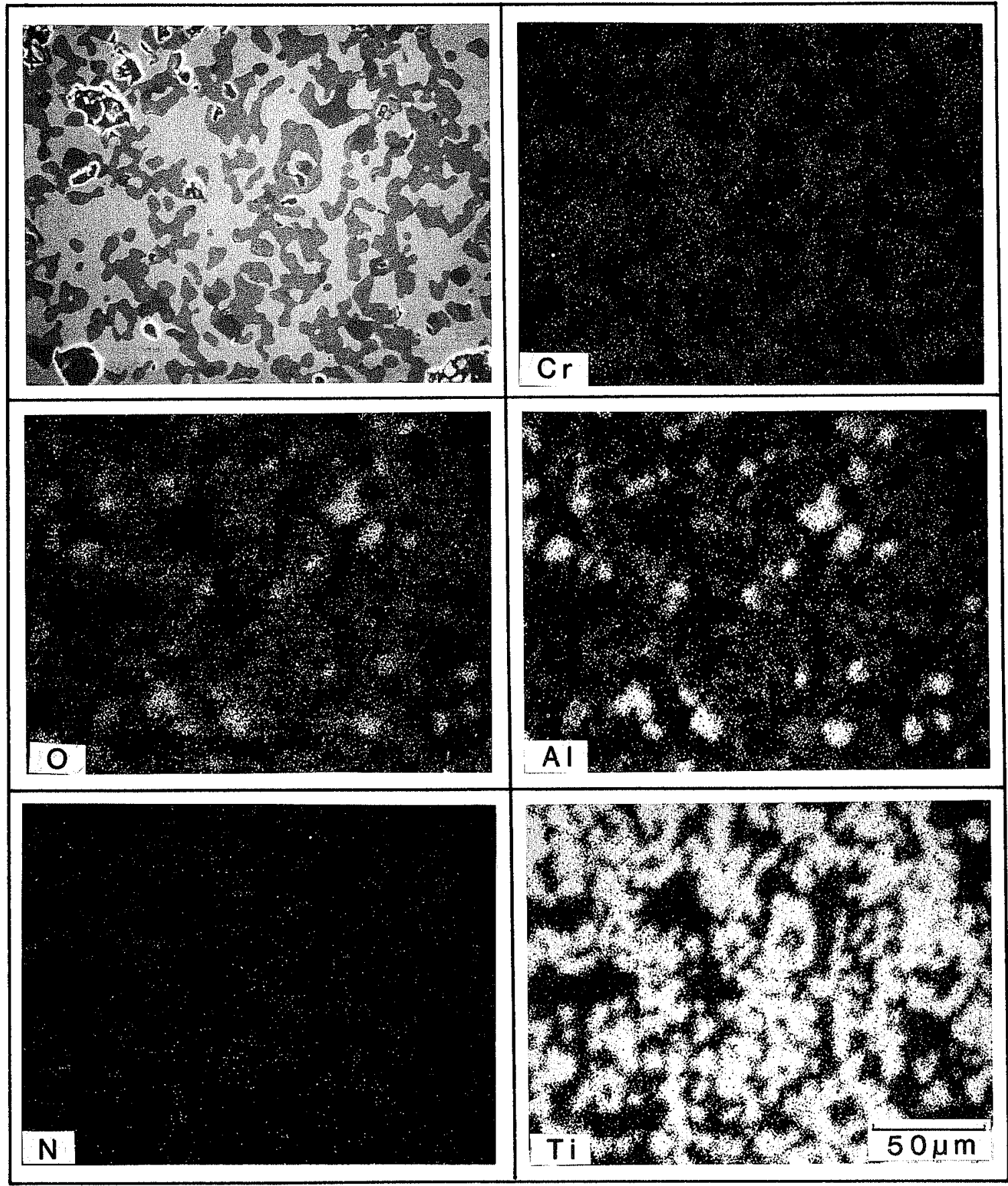

Fig. 4. EPMA image of the nozzle deposited materials shown in Fig. I(c).

Table 2. Proportions of the deposited materials. (mass\%)

\begin{tabular}{ccccccc}
\hline $\mathrm{Al}_{2} \mathrm{O}_{3}$ & $\mathrm{TiN}$ & $\mathrm{TiO}_{2}$ & $\mathrm{Ti}(\mathrm{C}, \mathrm{S})$ & $\mathrm{Cr}_{2} \mathrm{O}_{3}$ & $\mathrm{TiN}_{\mathrm{Al}} \mathrm{O}_{3}$ & $\mathrm{TiO}_{2} / \mathrm{Al}_{2} \mathrm{O}_{3}$ \\
\hline 2.946 & 0.231 & 6.03 & 0.15 & 0.175 & 0.078 & 2.05 \\
\hline
\end{tabular}


with that in Fig. 3(a). The curved chain of globular Ti oxides can be seen in the sample close to the refractory as shown in Fig. 3(c).

The chemical composition of the material in Fig. 3(c) was analyzed by EPMA and is shown in Fig. 4. The gray and curved chain materials are Ti oxide, while the large black particles are $\mathrm{Al}_{2} \mathrm{O}_{3}$. These particles are surrounded by solidified steel

The clogging materials were dissolved with $10 \%$ bromine methanol and $A A$ electrolyte (10\% acetylacetone $-1 \%$ tetramethylammonium chloride methanol) to clarify the proportion of these materials. As shown in Table 2, the major materials were $\mathrm{Ti}$ oxide and $\mathrm{Al}_{2} \mathrm{O}_{3}$ in a ratio $\left(\mathrm{TiO}_{2} / \mathrm{Al}_{2} \mathrm{O}_{3}\right)$ of 2.05 . Ti sulfide, Ti nitride

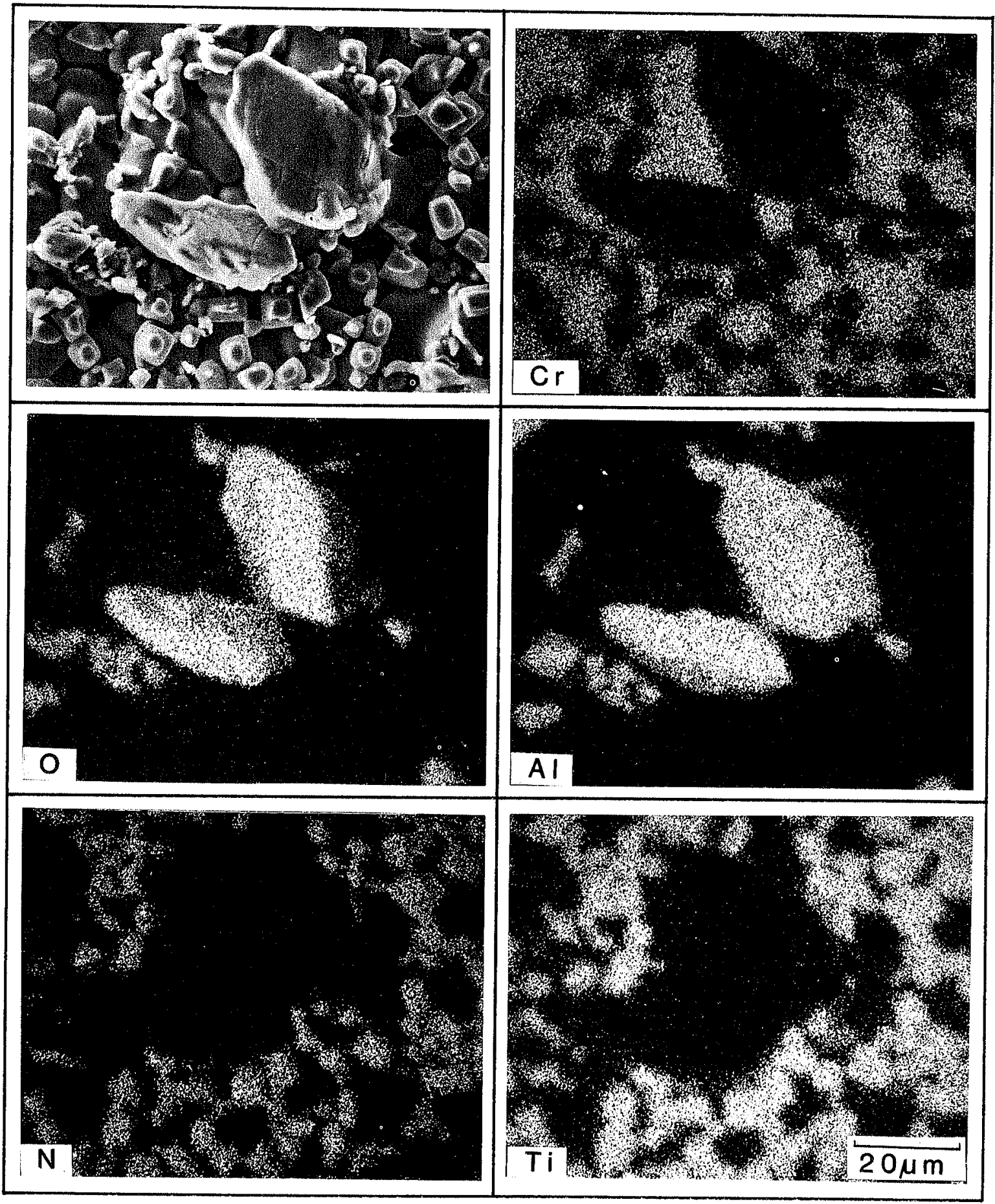

Fig. 5. EPMA image of the non-metallic inclusions in the tundish sample.

Table 3. Proportions of the inclusions in the tundish sample. (masso)

\begin{tabular}{ccccccc}
\hline $\mathrm{Al}_{2} \mathrm{O}_{3}$ & $\mathrm{TiN}$ & $\mathrm{TiO}_{2}$ & $\mathrm{Ti}(\mathrm{C}, \mathrm{S})$ & $\mathrm{Cr}_{2} \mathrm{O}_{3}$ & $\mathrm{TiN}_{\mathrm{Al}} \mathrm{O}_{3}$ & $\mathrm{TiO}_{2} / \mathrm{Al}_{2} \mathrm{O}_{3}$ \\
\hline 0.0075 & 0.03 & 0.001 & 0.035 & 0.001 & 4.0 & 0.133 \\
\hline
\end{tabular}




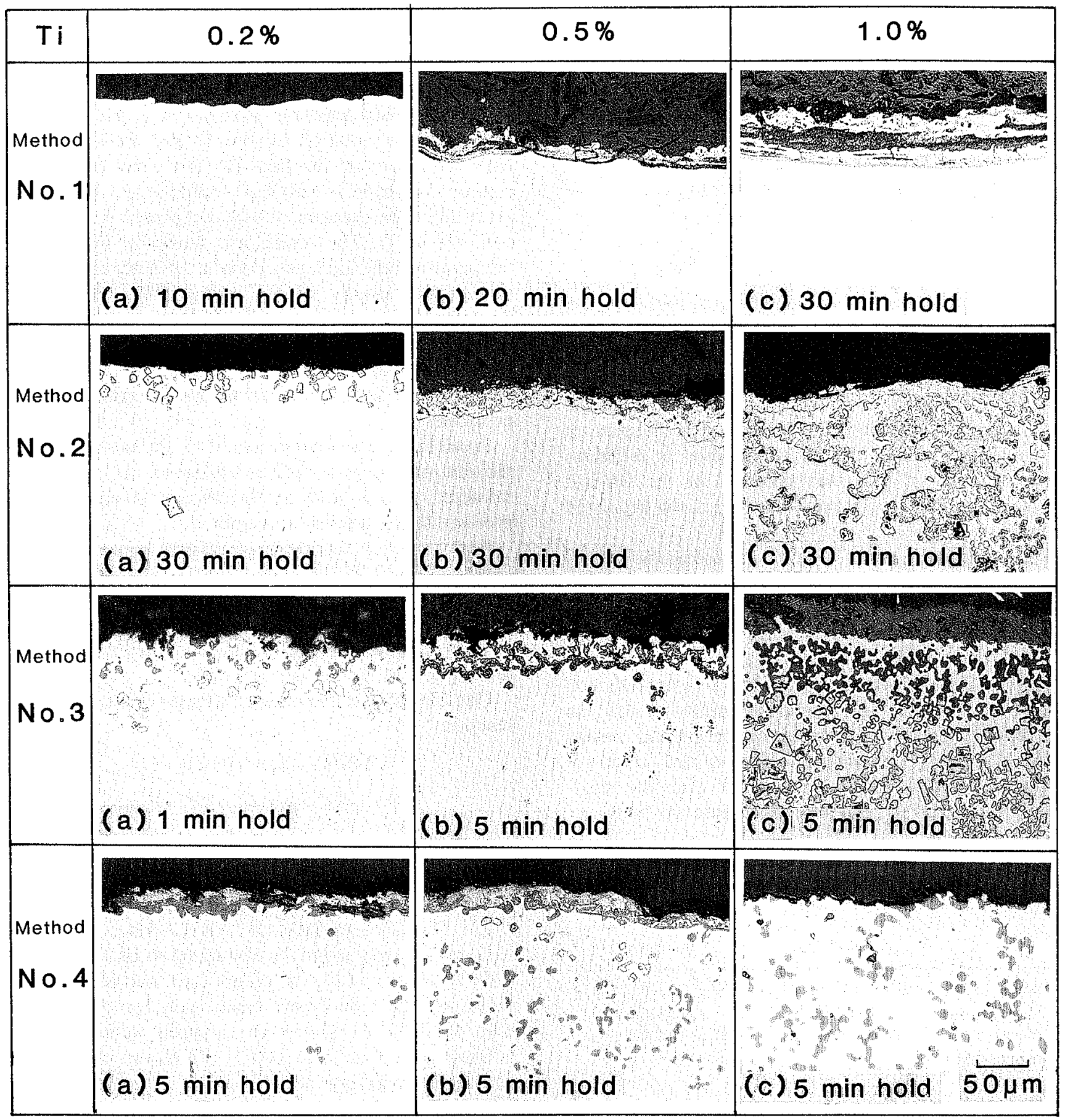

Fig. 6. Microstructures of the non-metallic inclusions from the laboratory experiments.

and Ti carbide were scarcely found.

\subsection{Inclusions in the Steel in the Tundish}

The sample from the tundish was remelted by the electron beam extraction method. The inclusions that floated up to the surface of the sample were then analyzed by EPMA as shown in Fig. 5. The large black agglomerated inclusions are $\mathrm{Al}_{2} \mathrm{O}_{3}$, while the small transparent inclusions are $\mathrm{TiN}$.

According to the chemical analysis of the nonmetallic inclusions in the steel in the tundish, the proportions of the materials are also shown in Table 3.

\subsection{Laboratory Test Results}

The microstructures from the four laboratory treat- ments are shown in Fig. 6. With treatment Method No. i, a thin oxidized layer was found after holding for 20 min on the surface of the sample, which composition was identified as of $\mathrm{FeO}, \mathrm{Cr}_{2} \mathrm{O}_{3}$ and $\mathrm{Al}_{2} \mathrm{O}_{3}$ by EPMA analysis. Ti oxide was not observed in spite of the high Ti content of the melt.

As was expected, continuous granular TiN was formed at the surface of the sample with treatment Method No. 2. Ti oxide and TiN were observed around the surface of the sample No. 3a. Longer holding time and higher Ti content made the transition from TiN to Ti oxide accelerate as shown in Nos. $3 b$ and $3 c$.

Three kinds of reacted substances were observed in No. 3c. On the top of the sample, tightly packed Ti 
oxide was formed. The curved chain of globular $\mathrm{Ti}$ oxide, which were found in the deposited materials in plant operation, was observed just below the surface of the sample. A cluster of TiN was identified away from the surface, and careful observation indicated that this TiN was enclosed by globular Ti oxide.

By substituting $\mathrm{FeO}$ powder for the oxygen atmosphere, the same kind of result was obtained, as shown in Nos. $4 a, 4 b$ and $4 c$.

\section{Discussion}

The composition of non-metallic inclusions in the nozzle deposit and in the steel in the tundish, which were extracted by dissolving with bromine methanol, is summarized in Table 4 . When considering the amounts of alumina, $\mathrm{Ti}$ oxide and $\mathrm{TiN}$ in the sample from the tundish and the sample from the deposited material on the immersed nozzle, the major material is different. Large amount of TiN was detected in the tundish sample, whereas Ti oxide predominated in the deposited material.

This difference has not been recognized in the case of conventional aluminum-killed steel. Namely, the deoxidation products of $\mathrm{Al}_{2} \mathrm{O}_{3}$ in the steel melt in the tundish, deposit at the inner surface of the nozzle as the steel passes through the nozzle. ${ }^{1,6)}$

However, the information from the present study can not be explained by the simple deposition model. On the other hand, the laboratory experimental results show interesting information. The curved chain of globular Ti oxide could only be found after the reoxidation following nitrogen absorption into the melt.

Table 4. Composition of the non-metallic inclusions in the deposited material of the nozzle and those in the steel melt in the tundish.

\begin{tabular}{ccc}
\hline & AA method & $\mathrm{Br}_{2}$ method \\
\hline $\begin{array}{c}\text { Tundish sample } \\
\text { Nozzle deposited } \\
\text { material }\end{array}$ & $\mathrm{TiN}, \mathrm{Ti}(\mathrm{C}, \mathrm{N}), \mathrm{Al}_{2} \mathrm{O}_{3}$ & $\mathrm{TiN}, \mathrm{Ti}(\mathrm{C}, \mathrm{N}), \mathrm{Al}_{2} \mathrm{O}_{3}$ \\
$\mathrm{TiO}_{2}, \mathrm{Al}_{2} \mathrm{O}_{3}$ & $\mathrm{TiO}_{2}, \mathrm{Al}_{2} \mathrm{O}_{3}$ \\
& $\mathrm{Ti}_{2} \mathrm{O}_{3}, \mathrm{TiN}, \mathrm{Fe}_{2} \mathrm{O}_{3}$ & $\mathrm{Ti}_{2} \mathrm{O}_{3}, \mathrm{TiN}, \mathrm{Fe}_{2} \mathrm{O}_{3}$ \\
\hline
\end{tabular}

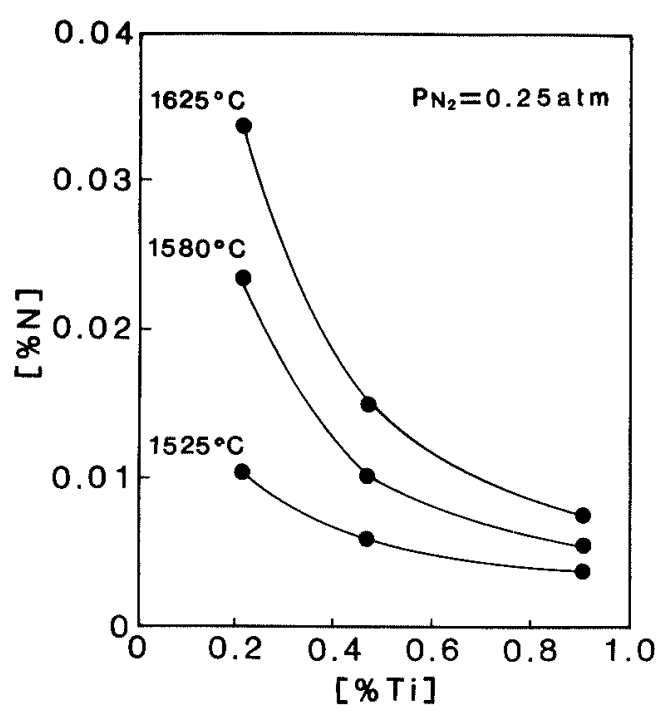

Fig. 7. Solubility of nitrogen in liquid SUS409 stainless steel.
Precipitated TiN reacts with oxygen and decomposes to this uniquely shaped $\mathrm{Ti}$ oxide. Thus, TiN precipitation in the steel melt in the tundish would promote the deposition tendency in plant operation.

The solubility limit for nitrogen in a stainless steel melt has been studied for $\mathrm{Fe}-\mathrm{Ti}$ and $\mathrm{Fe}-\mathrm{Cr}-\mathrm{Ti}$ systems. ${ }^{7,8)}$ However, the data are not clear enough for commercial grade Ti-stabilized stainless steel. Therefore, an equilibrium experiment was performed for different contents of $\mathrm{Ti}$. The results are shown in Fig. 7. The temperature and nitrogen content of steel melt in the tundish are usually $1565^{\circ} \mathrm{C}$ and $0.02 \%$, respectively. Therefore, the casting condition is close to the precipitation limit of TiN. When considering the additional temperature drop from the tundish to mold, TiN precipitation in the immersed nozzle is considered to be probable.

Possible oxygen sources would be the many kinds of reoxidation processes such as leakage of air through the refractory joints and an insufficient oxygen partial pressure in the tundish atmosphere.

For example, the porosity of zirconia immersed nozzle $\left(\mathrm{ZrO}_{2} / 73-78 \%, \mathrm{SiC} / 9-11 \%, \mathrm{~F} . \mathrm{C} / 12-15 \%\right)$ cemented at the base of a tundish is $11-15 \%$. When liquid steel passes through the nozzle, the diffusion of oxygen (or air) through the pores of the nozzle would cause oxidation of TiN at the surface of nozzle.

Considering the free-energy change of the following reaction: ${ }^{9,10)}$

$$
\begin{gathered}
\operatorname{TiN}(\mathrm{s})+2 \underline{\mathrm{O}}=\mathrm{TiO}_{2}(\mathrm{~s})+\underline{\mathrm{N}} \ldots \ldots . \\
\Delta G=-332346+100.60 T \quad(\mathrm{~J} / \mathrm{mol}) \\
\log \left(a_{\mathrm{N}} /{a_{\mathrm{O}}}^{2}\right)=-5.255+17360 / T \ldots
\end{gathered}
$$

Under the condition of nitrogen content of $0.02 \%$, the activity of oxygen that exceeds $7.2 \mathrm{ppm}$ can proceed to the formation of $\mathrm{TiO}_{2}$ at $1600^{\circ} \mathrm{C}$. Also, the critical value for oxygen activity is calculated to be $4.14 \mathrm{ppm}$ at $1600^{\circ} \mathrm{C}$ when $\mathrm{Ti}_{3} \mathrm{O}_{5}$ is taken into consideration. ${ }^{11)}$ However, the equilibrium calculation for deoxidation with $0.013 \% \mathrm{Al}$ shows the oxygen activity to be $5.2 \mathrm{ppm}$ and that with $0.16 \% \mathrm{Ti}$ shows the oxygen activity to be $2.5 \mathrm{ppm}$ at $1600^{\circ} \mathrm{C}$.

Therefore, the formation of $\mathrm{Ti}$ oxide through the decomposition of TiN can not be expected without additional reoxidation during the casting process. This postulation is in good agreement with the results of the present investigation.

Thus, the following measures would be effective for reducing the deposition problem with Ti-stabilized stainless steel.

1) Reduce the nitrogen in the steel melt.

2) Reduce reoxidation during the casting operation.

3) Reduce the temperature drop at the immersed nozzle by enhancing thermal insulation.

\section{Conclusions}

The formation mechanism for clogging materials in the immersed nozzle during the continuous casting of Ti-stabilized stainless steel was investigated. The results 
obtained are as follows.

(1) The deposited materials were curved chain of globular Ti oxide.

(2) The major non-metallic inclusions in the tundish were $\mathrm{TiN}$ and $\mathrm{Al}_{2} \mathrm{O}_{3}$, while, $\mathrm{Ti}$ oxide was scarcely found.

(3) The laboratory test made it clear that these curved chain of globular Ti oxide could be formed only by reoxidation after adding nitrogen to the melt.

(4) The $\mathrm{Ti}$ oxide with unique shape observed in the deposited material is the reaction product of TiN with oxygen. This reaction was proposed to be the formation mechanism of deposited material for $\mathrm{Ti}$ stabilized stainless steel.

\section{REFERENCES}

1) S. N. Singh: Metall. Trans., 5 (1974), 2165.

2) T. Onishi: Refractories (Taikabutu), 26 (1974), 128.

3) K. Oki: Refractories (Taikabutu), 32 (1980), 626.

4) M. Hasegawa: Tetsu-to-Hagané, 70 (1984), 1704.

5) I. Takahashi: Nippon Stainless Tech. Rep., 20 (1985), 45.

6) H. Kyoden: Refractories (Taikabutu), 34 (1982), 382.

7) Z. Morita and K. Kunisada: Tetsu-to-Hagané, 63 (1977), 1663.

8) H. Wada, K. Gunji and T. Wada: J. Jpn. Inst. Met., 32 (1968), 933.

9) H. Wada and R. Pehlke: Metall. Trans., 8B, (1977), 443.

10) M. Hasegawa: Tetsu-to-Hagané, 73 (1987), 50.

11) K. Suzuki and K. Sanbongi: Trans. Iron Steel Inst. Jpn., 15 (1975), 618. 